\title{
Photoinduced Electron and Energy Transfer in a Molecular Triad Featuring a Fullerene Redox Mediator
}

Antaeres Antoniuk-Pablant, Gerdenis Kodis, Ana L. Moore, ${ }^{*}$ Thomas A. Moore, ${ }^{*}$ and Devens Gust*

School of Molecular Sciences, Arizona State University, Tempe, AZ 85287

\section{Synthesis}

Instrumental techniques. All NMR spectra were recorded on $400 \mathrm{MHz}$ Varian spectrometers. Samples were dissolved in $\mathrm{CDCl}_{3}$ with TMS as an internal reference unless otherwise stated. Mass spectra were obtained using one of three instruments as noted. An Applied Biosystems Voyager-DE STR matrix-assisted laser desorption/ionization time-of-flight spectrometer (MALDI-TOF) was used at the Proteomics lab at Arizona State University. A Shimadzu Axima cfr-plus matrix-assisted laser desorption/ionization time-of-flight spectrometer (MALDI-TOF) and a high resolution Waters Xevo G2-XS UPLC/MS/MS electrospray (ESI) was employed in the Mass Spectrometry and Metabolomics Core at Michigan State University. Trans, trans-1,4-diphenyl-1,3-butadiene was used as a matrix for the Applied Biosystems Voyager-DE STR MALDI-TOF-MS measurements unless otherwise stated. $\alpha$ Cyano-4-hydroxycinnamic acid was used as a matrix for the Shmadzu Axima cfr-plus MALDI-TOFMS measurement. Ultraviolet-visible absorption spectra were measured on a Shimazu UV2100U spectrometer.

General procedures. Thin-layer chromatography for dipyrromethanes and porphyrins was performed on silica gel GHFL or GHL plates (Analtech). Synthesis, workup and purification were performed in a darkened laboratory. 5-(4-t-Butylphenyl)dipyrromethane (13) $)^{\mathrm{S} 1}$ 5-(4methoxycarbonylphenyl)-10,15,20-tris(4-t-butylphenyl)porphyrin $\quad(14)^{\mathrm{S} 2}, \quad$ and $\quad 5-(2,4,6-$ trimethylphenyl)dipyrromethane $(10)^{\mathrm{S} 3}$ were prepared following previously reported methods.

N-Benzoyl-p-chloromethyl-D,L-phenylglycine (6). Compound 6 was prepared by modifying previously reported methods. ${ }^{\mathrm{S} 4}$ Benzyl chloride $(5.3 \mathrm{~g}, 41.7 \mathrm{mmol})$ and $\alpha$-hydroxyhippuric acid $(1.95 \mathrm{~g}$, $1.00 \mathrm{mmol}$ ) were added to a round bottomed flask under argon and equipped with a magnetic stir bar. Methane sulfonic acid (99.5\%) (10 mL) was added and the solution was allowed to stir for $48 \mathrm{~h}$ at room temperature under argon. The reaction mixture was poured into ice water and was extracted with ethyl acetate. The organic layer was washed with water $(3 \times 50 \mathrm{~mL})$ and then dried over anhydrous sodium sulfate. The solvent was removed by distillation under reduced pressure, the resulting oil was dissolved in dichloromethane, and the compound was purified by column chromatography on silica gel using 50\% ethyl acetate in dichloromethane as the solvent. After the first band was removed the eluent was switched to $50 \%$ ethyl acetate and $8 \% \mathrm{MeOH}$ in dichloromethane. The solvent was removed by distillation under reduced pressure and the product was purified by recrystallization from dichloromethane/hexane to yield compound 6 as white crystals $(26.0 \%, 4.2 \mathrm{~g}) .{ }^{1} \mathrm{H}$ NMR, $\left(\mathrm{CD}_{3} \mathrm{OD}\right) \delta$ (ppm) 7.81 - 7.90 (m, 2 H), 7.31 - 7.62 (m, 7 H), 5.70 (br s, 1 H), 4.65 (s, 2 H). Xevo G2-XS QTOF LCMS/MS, ESI, m/z; calcd for $\mathrm{C}_{16} \mathrm{H}_{14} \mathrm{ClNO}_{3} 304.07$ [M+], obsd 304.07.

N-Benzyloxycarbonyl-p-hydroxymethyl-D,L-phenylglycine (7). Compound 7 was prepared following the previously reported method ${ }^{\mathrm{S} 4}$ with modifications. Compound 6 (1.4 g, $\left.4.6 \mathrm{mmol}\right)$ and $\mathrm{K}_{2} \mathrm{CO}_{3}$ (400 mg, $2.90 \mathrm{mmol}$ ) were dissolved in $70 \mathrm{~mL}$ of water in a round bottomed flask equipped with a magnetic stir bar. The solution was stirred at room temperature for $48 \mathrm{~h}$, after which concentrated $\mathrm{HCl}$ was added dropwise until the solution was at $\mathrm{pH} 3$, upon which a white precipitate formed. The solution was then extracted with ethyl acetate, the organic layer was washed with water $(3 \times 100 \mathrm{~mL})$, the organic layer was collected and dried over anhydrous sodium sulfate, and the solvent was removed by distillation under reduced pressure. The product was dried under reduced pressure yielding compound 7 as white crystals $(1 \mathrm{~g}, 46 \%)$. The product contained a trace of the hydrochloride form. ${ }^{1} \mathrm{H} \mathrm{NMR}$, 
$\left(\mathrm{CD}_{3} \mathrm{OD}\right) \delta(\mathrm{ppm}) 7.82$ - $7.88(\mathrm{~m}, 2 \mathrm{H}), 7.34-7.58(\mathrm{~m}, 7 \mathrm{H}), 5.67$ (s, $\left.1 \mathrm{H}\right), 4.61(\mathrm{~s}, 2 \mathrm{H})$. Xevo G2-XS QTOF LC-MS/MS, ESI, m/z; calcd for $\mathrm{C}_{16} \mathrm{H}_{15} \mathrm{NO}_{4} 286.11[\mathrm{M}+]$, obsd 286.11.

N-Benzoyl-p-hydroxymethyl-DL-phenylglycine methyl ester (8). All glassware used had no ground glass joints. Compound $7(500 \mathrm{mg}, 1.67 \mathrm{mmol})$ was dissolved in ethyl acetate $(100 \mathrm{~mL})$ in an Erlenmeyer flask equipped with a magnetic stir bar, and the flask was placed in an ice bath. In a separate two neck round bottomed flask equipped with a condenser in one neck which was positioned to condense into the Erlenmeyer flask and a separatory funnel in the other, $\mathrm{KOH}(2.0 \mathrm{~g}, 0.040 \mathrm{~mol})$ was dissolved in a solution of ethanol $(20 \mathrm{~mL})$ and water $(8 \mathrm{~mL})$. A solution of Diazald $(1 \mathrm{mg}, 5 \mathrm{mmol})$ dissolved in diethyl ether $(15 \mathrm{~mL})$ was added to the separatory funnel. The round bottomed flask was placed in an oil bath heated at $70^{\circ} \mathrm{C}$, and the solution in the separatory funnel was added dropwise to the round bottomed flask generating diazomethane which then condensed along with diethyl ether into the Erlenmeyer flask. After $15 \mathrm{~min}$ the reaction was complete as indicated by thin layer chromatography, and acetic acid $(1 \mathrm{~mL})$ was added to the solution. The solvent was removed by distillation under reduced pressure, and the product was dissolved in dichloromethane and washed with an aqueous solution of $\mathrm{NaHCO}_{3}$ followed by water $(2 \times 100 \mathrm{~mL})$. The solvent was removed by distillation under reduced pressure and the product was dried under vacuum and purified by column chromatography on silica gel using 50\% ethyl acetate in dichloromethane. The second band was collected and the solvent was removed by distillation under reduced pressure yielding pure product 8 as white crystals $(400 \mathrm{mg}, 76 \%) .{ }^{1} \mathrm{H}$ NMR, $\delta(\mathrm{ppm}) 7.79-7.85(2 \mathrm{H}, \mathrm{m}), 7.35$ - $7.56(7 \mathrm{H}, \mathrm{m}), 7.17(1 \mathrm{H}, \mathrm{d}$, $J=6 \mathrm{~Hz},-\mathrm{NH}), 5.78(1 \mathrm{H}, \mathrm{d}, J=7 \mathrm{~Hz}), 4.70(2 \mathrm{H}, \mathrm{d}, J=6 \mathrm{~Hz}), 3.77(3 \mathrm{H}, \mathrm{s})$. Xevo G2-XS QTOF LCMS/MS, ESI, m/z; calcd for $\mathrm{C}_{17} \mathrm{H}_{17} \mathrm{NO}_{4} 300.12$ [M+], obsd 300.12.

N-Benzoyl-p-formyl-D,L-phenylglycine methyl ester (9) Compound 8 (200 mg, 0.670 mmol) was dissolved in distilled tetrahydrofuran $(10 \mathrm{~mL})$ in a round bottomed flask equipped with a magnetic stir bar. Dess-Martin periodinane $(595 \mathrm{mg}, 1.40 \mathrm{mmol})$ was added and the solution was stirred for $2.5 \mathrm{~h}$. A portion of $\mathrm{Na}_{2} \mathrm{~S}_{2} \mathrm{O}_{3}(1.83 \mathrm{~g}, 7.37 \mathrm{mmol})$ was dissolved in a solution of $80 \% \mathrm{Na}_{2} \mathrm{HCO}_{3}$ in water $(30$ $\mathrm{mL}$ ) and this solution was added to the reaction mixture, which was then stirred for an additional 20 min. The solution was extracted with ethyl acetate, and the organic layer was collected and washed with water $(3 \times 50 \mathrm{~mL})$. The water washes were extracted with dichloromethane, the organic layers were combined and the solvent was removed by distillation under reduced pressure. The product was dried under reduced pressure and purified by column chromatography on silica gel with $30 \%$ dichloromethane in EtOAc as the solvent to give pure $8(100 \mathrm{mg}, 40 \%) .{ }^{1} \mathrm{H} \mathrm{NMR}, \delta(\mathrm{ppm}) 10.01(1 \mathrm{H}, \mathrm{s}), 7.89(2 \mathrm{H}, \mathrm{d}$, $J=8 \mathrm{~Hz}), 7.84$ (2 H, d, $J=8 \mathrm{~Hz}), 7.63$ (2 H, d, $J=8 \mathrm{~Hz},), 7.50-7.58$ (1 H, m), 7.43 - 7.50 (2 H, m), 7.36 (1 H, d, J=6 Hz, -NH), 5.86 (1 H, d, J=7 Hz,), 3.80 (3 H, s). Xevo G2-XS QTOF LC-MS/MS, ESI, m/z; calcd for $\mathrm{C}_{17} \mathrm{H}_{15} \mathrm{NO}_{4} 298.11[\mathrm{M}+]$, obsd 298.11

N-Benzoyl- 4-[10,15,20-tris(2,4,6-trimethylphenylporphyrin-5-yl]phenylglycine, methyl ester (12) Compound 9 (427 mg, $1.44 \mathrm{mmol})$, dipyrromethane 10 (1.5 g, $5.7 \mathrm{mmol})$, and mesitaldehyde (427 mL, $2.90 \mathrm{mmol})$, were dissolved in dry and deoxygenated dichloromethane $(300 \mathrm{~mL})$ under argon in a round bottomed flask equipped with a magnetic stir bar. Trifluoroacetic acid $(0.41 \mathrm{~mL}, 5.3 \mathrm{mmol})$ was added dropwise and the solution was stirred for $2 \mathrm{~h}$ at room temperature. To the solution was added 2,3-dichloro-5,6-dicyano-1,4-benzoquinone $(653 \mathrm{mg}, 2.88 \mathrm{mmol})$ and the solution was stirred for $3 \mathrm{~h}$. Next, triethylamine $(0.30 \mathrm{~mL}, 2.2 \mathrm{mmol})$ was added and the solution was stirred for $10 \mathrm{~min}$. The solvent was removed by distillation under reduced pressure and the product was purified by column chromatography on silica gel with a solution of 35\% hexanes in dichloromethane; after the first band was removed dichloromethane was used as the solvent, and after the second band was removed a solution of 5\% ethyl acetate in dichloromethane was used to give pure product 12 as purple crystals, $\mathrm{mp}$ $>300{ }^{\circ} \mathrm{C},(20 \mathrm{mg}, 1.5 \%) .{ }^{1} \mathrm{H} \mathrm{NMR}, \delta(\mathrm{ppm}) 8.77(2 \mathrm{H} \mathrm{d}, J=5 \mathrm{~Hz}), 8.67(2 \mathrm{H}, \mathrm{d}, J=5 \mathrm{~Hz}),, 8.62(\mathrm{~s}, 4 \mathrm{H})$, $8.21(2 \mathrm{H}, \mathrm{d}, J=8 \mathrm{~Hz}), 7.99(2 \mathrm{H}, \mathrm{d}, J=7 \mathrm{~Hz}), 7.82(2 \mathrm{H}, \mathrm{d}, J=8 \mathrm{~Hz}), 7.48-7.63(3 \mathrm{H}, \mathrm{m}), 7.43$ (1 H, d, $J=7 \mathrm{~Hz}), 7.27(6 \mathrm{H}$, br s), $6.17(1 \mathrm{H}, \mathrm{d}, J=7 \mathrm{~Hz}), 3.97(3 \mathrm{H}, \mathrm{s}), 2.55-2.68(9 \mathrm{H}, \mathrm{m}), 1.84(18 \mathrm{H}, \mathrm{d}, J=4$ 
Hz), -2.57 (2 H, s). Xevo G2-XS QTOF LC-MS/MS, ESI, m/z; calcd for $\mathrm{C}_{63} \mathrm{H}_{57} \mathrm{~N}_{5} \mathrm{O}_{3} 932.45[\mathrm{M}+]$, obsd 932.45 .

4-[10,15,20-tris(2,4,6-Trimethylphenylporphyrin-5-yl]phenylglycine (4). Porphyrin 12 (10 $\mathrm{mg}, 0.011 \mathrm{mmol})$ was dissolved in trifluoroacetic acid $(2 \mathrm{~mL})$, in a glass pressure tube equipped with a magnetic stir bar. A portion of $6 \mathrm{~N} \mathrm{HCl}(5 \mathrm{~mL})$ was added to the solution, the sealed pressure tube was placed in an oil bath at a temperature of $80^{\circ} \mathrm{C}$ and the solution was stirred for 4 days at $80^{\circ} \mathrm{C}$. The solution was allowed to cool to room temperature and was extracted with $10 \mathrm{~mL}$ of dichloromethane. The organic layer was washed with a solution of saturated $\mathrm{NaHCO}_{3}(100 \mathrm{~mL})$, followed by water $(100$ $\mathrm{mL})$, and finally $0.1 \mathrm{M}$ citric acid $(100 \mathrm{~mL})$. The organic layer was collected, dried over anhydrous sodium sulfate and dried under reduced pressure for $4 \mathrm{~h}$ to give porphyrin 4 as purple crystals. The mass spectrum of the compound was analyzed and no further characterization was done due to the instability of porphyrin 4; the next synthetic step was carried out immediately, (7 mg, 78.2\%). Shmadzu Axima cfr-plus MALDI-TOF-MS, m/z; calcd for $\mathrm{C}_{55} \mathrm{H}_{51} \mathrm{~N}_{5} \mathrm{O}_{2} 814.03$ [M+], obsd 813.46.

Porphyrin P-C 6 dyad (2) Dyad 2 was synthesized using a general procedure for the functionalization of a $\mathrm{C}_{60}$ as a guide. ${ }^{\mathrm{S}}$ Porphyrin $4(6 \mathrm{mg}, 0.007 \mathrm{mmol})$ was dissolved in distilled toluene $(15 \mathrm{~mL})$ in a round bottomed flask equipped with a magnetic stir bar and a reflux condenser. To the solution $p$-tolualdehyde $(2 \mathrm{mg}, 0.02 \mathrm{mmol})$, and $\mathrm{C}_{60}(6 \mathrm{mg}, 0.008 \mathrm{mmol})$ was added, and the reaction flask was placed in an oil bath that was slowly brought to a temperature of $120^{\circ} \mathrm{C}$. The solution was refluxed for $16 \mathrm{~h}$, after which it was cooled to room temperature and solvent was removed by distillation under reduced pressure. The product was purified by preparative thin layer chromatography with $30 \%$ dichloromethane in hexane as the solvent to give 2 as a yellow/brown solid (4 mg, 36\%). ${ }^{1} \mathrm{H}$ NMR $\delta$ (ppm) $8.56-8.75(8 \mathrm{H}, \mathrm{m}), 8.38(2 \mathrm{H}, \mathrm{d}, J=8 \mathrm{~Hz}),, 8.23-8.31(2 \mathrm{H}, \mathrm{m}), 8.00(2 \mathrm{H}, \mathrm{d}, J=8 \mathrm{~Hz}), 7.31(2$ H, d, J=8 Hz,), $7.25(6 \mathrm{H}, \mathrm{s}), 6.33(1 \mathrm{H}, \mathrm{s}), 6.15(1 \mathrm{H}, \mathrm{s}), 2.60(9 \mathrm{H}, \mathrm{s}), 2.40(3 \mathrm{H}, \mathrm{s}), 1.77$ - 1.87 (18 H, m), -2.58 (2 H, s); Voyager-DE STR MALDI-TOF-MS, m/z; calcd for $\mathrm{C}_{62} \mathrm{H}_{57} \mathrm{~N}_{5} 872.15$ [M+ - $\mathrm{C}_{60}$ ], obsd 871.91; calcd for $\mathrm{C}_{122} \mathrm{H}_{57} \mathrm{~N}_{5} 1591.46[\mathrm{M}+]$, obsd 1591.46.

5-[(4-(Hydroxymethyl)phenyl]-10,15,20-tris(4-t-butylphenyl)porphyrin (15). Porphyrin 14 $(500 \mathrm{mg}, 0.59 \mathrm{mmol})$ was dissolved in anhydrous THF $(60 \mathrm{~mL})$ and the resulting solution degassed with argon in a round bottomed flask equipped with a magnetic stir bar. A portion of $\mathrm{LiAlH}_{4}(90 \mathrm{mg}, 2.4$ mmol) was added to the reaction flask, and the solution was stirred under argon at room temperature for $15 \mathrm{~min}$. The reaction was quenched with methanol dropwise until no further reaction was observed. The solvent was removed by distillation under reduced pressure and the products were dissolved in dichloromethane and washed with $1 \mathrm{~N} \mathrm{HCl}(100 \mathrm{~mL})$, followed by saturated aqueous $\mathrm{NaHCO}_{3}(100 \mathrm{~mL})$ and then water $(100 \mathrm{~mL})$ to give pure porphyrin 15 as purple crystals, mp $>300{ }^{\circ} \mathrm{C}(450 \mathrm{mg}, 93 \%) .{ }^{1} \mathrm{H}$ NMR $\delta(\mathrm{ppm}) 8.82$ - $9.01(6 \mathrm{H}, \mathrm{m}), 8.66$ - $8.79(2 \mathrm{H}, \mathrm{m}), 8.20$ - $8.33(2 \mathrm{H}, \mathrm{m}), 8.06$ - 8.18 (6 H, m), 7.67 - $7.84(8 \mathrm{H}, \mathrm{m}), 5.64(2 \mathrm{H}, \mathrm{s}), 1.60(27 \mathrm{H}, \mathrm{s}),-2.76(2 \mathrm{H}, \mathrm{br}$ s); Voyager-DE STR MALDI-TOF-MS, $\mathrm{m} / \mathrm{z}$; calcd for $\mathrm{C}_{57} \mathrm{H}_{56} \mathrm{~N}_{4} \mathrm{O} 813.08[\mathrm{M}+]$, obsd 812.98.

5-(4-Formylphenyl)-10,15,20-tris(4-t-butylphenyl)porphyrin (16). Porphyrin 15 (450 mg, $0.550 \mathrm{mmol})$ was dissolved in anhydrous tetrahydrofuran $(100 \mathrm{~mL})$ in a round bottomed flask equipped with a magnetic stir bar. Next, $\mathrm{MnO}_{2}(480 \mathrm{mg}, 5.53 \mathrm{mmol})$ was added in small portions over a period of $30 \mathrm{~min}$. After addition was complete, the reaction mixture was filtered through Celite, and the product was purified by column chromatography on silica gel with $0.2 \%$ acetone in dichloromethane to give pure porphyrin 15 as purple crystals, $\mathrm{mp}>300{ }^{\circ} \mathrm{C},(326 \mathrm{mg}, 40 \%) .{ }^{1} \mathrm{H} \mathrm{NMR} \delta(\mathrm{ppm}) 10.37(1 \mathrm{H}, \mathrm{s}), 8.83$ - $8.95(6 \mathrm{H}, \mathrm{m}), 8.75(2 \mathrm{H}, \mathrm{d}, J=5 \mathrm{~Hz}), 8.40(2 \mathrm{H}, \mathrm{d}, J=8 \mathrm{~Hz}),, 8.26(2 \mathrm{H}, \mathrm{d}, J=8 \mathrm{~Hz}),$,8.08 - $8.20(6 \mathrm{H}$, m), $7.76(6 \mathrm{H}, \mathrm{d}, J=8 \mathrm{~Hz}$ ), $1.61(27 \mathrm{H}, \mathrm{s}),-2.74(2 \mathrm{H}, \mathrm{s})$. Xevo G2-XS QTOF LC-MS/MS, ESI, m/z; calcd for $\mathrm{C}_{57} \mathrm{H}_{54} \mathrm{~N}_{4} \mathrm{O} 811.44[\mathrm{M}+]$, obsd 811.43.

7,8,17,18-Tetrabromo-5-(4-formylphenyl)-10,15,20-tris(4-t-butylphenyl)porphyrin Compound $16(260 \mathrm{mg}, 0.320 \mathrm{mmol})$ was dissolved in dichloromethane $(100 \mathrm{~mL})$ in a round bottomed flask equipped with a magnetic stir bar and a reflux condenser. Recrystallized $N$-bromosuccinimide (256 $\mathrm{mg}, 1.44 \mathrm{mmol}$ ) was added to the solution, and the flask was placed in an oil bath heated to $55^{\circ} \mathrm{C}$ and 
stirred for 45 min under argon and in the dark. Pyridine $(65 \mu \mathrm{L}, 0.81 \mathrm{mmol})$ was added to the reaction mixture and it was stirred for $2 \mathrm{~h}$. $\mathrm{N}$-bromosuccinimide $(150 \mathrm{mg}, 0.843 \mathrm{mmol})$, followed by pyridine $(65$ $\mu \mathrm{L}, 0.81 \mathrm{mmol})$ were added again and the solution was stirred for an additional $2 \mathrm{~h}$. A third portion of $N$-bromosuccinimide $(150 \mathrm{mg}, 0.843 \mathrm{mmol})$ followed by pyridine $(65 \mu \mathrm{L}, 0.81 \mathrm{mmol})$ was added to the reaction mixture and allowed to stir for another $3 \mathrm{~h}$. A final portion of $N$-bromosuccinimide $(150 \mathrm{mg}$, $0.843 \mathrm{mmol})$ and pyridine $(65 \mu \mathrm{L}, 0.81 \mathrm{mmol})$ were added and after $1 \mathrm{~h}$ the solution was allowed to cool to room temperature. The solvent was removed by distillation under reduced pressure and the product was purified by column chromatography on silica gel using $30 \%$ toluene in dichloromethane as the solvent to give pure 17 as purple crystals, $\mathrm{mp}>300{ }^{\circ} \mathrm{C}(90 \mathrm{mg}, 25 \%) .{ }^{1} \mathrm{H} \mathrm{NMR} \delta(\mathrm{ppm}) 10.38(1 \mathrm{H}, \mathrm{s})$, $8.79(1 \mathrm{H}, \mathrm{d}, J=5 \mathrm{~Hz}), 8.75(2 \mathrm{H}, \mathrm{s}), 8.59(1 \mathrm{H}, \mathrm{d}, J=3 \mathrm{~Hz}), 8.39(2 \mathrm{H}, \mathrm{d}, J=8 \mathrm{~Hz}),, 8.29(2 \mathrm{H}, \mathrm{d}, J=8 \mathrm{~Hz})$, 8.06 - 8.14 (6 H, m), $7.79(6 \mathrm{H}, \mathrm{d}, J=8 \mathrm{~Hz}), 1.59(27 \mathrm{H}, \mathrm{s}),-2.72(2 \mathrm{H}, \mathrm{d}, J=8 \mathrm{~Hz})$; Xevo G2-XS QTOF LC-MS/MS, ESI, m/z; calcd for $\mathrm{C}_{57} \mathrm{H}_{50} \mathrm{Br}_{4} \mathrm{~N}_{4} \mathrm{O} 1127.08$ [M+], obsd 1127.07.

Zn(II) 2,3,12,13-tetrabromo-5-(4-formylphenyl)-10,15,20-tris(4-t-butylphenyl) porphyrin (18). Porphyrin $17(87 \mathrm{mg}, 0.77 \mathrm{mmol})$ was dissolved in dichloromethane in a round bottomed flask equipped with a magnetic stir bar. Zinc acetate $(285 \mathrm{mg}, 1.55 \mathrm{mmol})$ and methanol $(6 \mathrm{~mL})$ were added to the solution, which was then stirred at room temperature for $6 \mathrm{~h}$. The solution was washed with water $(2 \times 100 \mathrm{~mL})$ and the organic layer was collected and dried over anhydrous sodium sulfate. The solvent was removed by distillation under reduced pressure and the product was purified by column chromatography on silica gel using dichloromethane as the solvent giving pure 18 as purple crystals, $\mathrm{mp}$ $>300{ }^{\circ} \mathrm{C}(80 \mathrm{mg}, 94.0 \%) ;{ }^{1} \mathrm{H} \mathrm{NMR} \mathrm{CD}{ }_{3} \mathrm{Cl}$ with $\left.2 \% \mathrm{CD}_{3} \mathrm{OD}\right) \delta(\mathrm{ppm}) 10.35(1 \mathrm{H}, \mathrm{s}), 8.72-8.78(3 \mathrm{H}$, m), 8.59 (1 H, d, J=5 Hz,), 8.17 - $8.31(4 \mathrm{H}, \mathrm{m}), 7.89$ - $7.99(6 \mathrm{H}, \mathrm{m}), 7.68$ - 7.78 (6 H, m), $1.59(27 \mathrm{H}$, br s); Xevo G2-XS QTOF LC-MS/MS, ESI, m/z; calcd for $\mathrm{ZnC}_{57} \mathrm{H}_{48} \mathrm{Br}_{4} \mathrm{~N}_{4} \mathrm{O} 1190.99$ [M+], obsd 1190.99

Zn(II) 2,3,12,13-tetracyano-5-(4-formylphenyl)-10,15,20-tris(4-t-butylphenyl) porphyrin (19). Porphyrin 18, $\mathrm{Zn}(\mathrm{OAc})_{2}, 1,1$ '-bis(diphenylphosphino)ferrocene, and $\mathrm{Zn}$ dust were each dried under reduced pressure overnight and all glassware was oven dried before use. $N, N$-Dimethylacetamide was stirred with $\mathrm{BaO}$ for $24 \mathrm{~h}$, then refluxed over $\mathrm{BaO}$ for $1 \mathrm{~h}$, and distilled under reduced pressure before use. Porphyrin 18 (65 mg $0.06 \mathrm{mmol})$, tris(dibenzylideneacetone)dipalladium(0) (40 mg, 0.04 mmol), 1,1'-bis(diphenylphosphino)ferrocene (49 mg, $0.09 \mathrm{mmol}), \mathrm{Zn}(\mathrm{OAc})_{2}$ (3 $\left.\mathrm{mg}, 0.01 \mathrm{mmol}\right), \mathrm{Zn}$ dust (2 mg, $0.03 \mathrm{mmol})$, and $\mathrm{Zn}(\mathrm{CN})_{2}(16 \mathrm{mg}, 0.14 \mathrm{mmol})$ were dissolved in deaerated dimethylacetamide $(10 \mathrm{~mL})$ in a Schlenk flask equipped with a magnetic stir bar. The Schlenk flask was placed in an oil bath which was brought to a temperature of $115^{\circ} \mathrm{C}$ and the reaction mixture was stirred under argon for $20 \mathrm{~h}$. Dichloromethane $(60 \mathrm{~mL})$ was added, the solution was washed 5 times with water $(100 \mathrm{~mL})$, the organic layer was collected, and the solvent was distilled under reduced pressure. The product was purified by column chromatography on silica gel with $20 \%$ ethyl acetate in toluene as the solvent. A final purification was done by recrystallization from dichloromethane and hexane to yield pure porphyrin 19 as purple crystals, $\mathrm{mp}>300{ }^{\circ} \mathrm{C}(10 \mathrm{mg}, 18.6 \%) ;{ }^{1} \mathrm{H} \mathrm{NMR} \delta(\mathrm{ppm}) 10.33(1 \mathrm{H}, \mathrm{s})$, $8.75(2 \mathrm{H}, \mathrm{br} \mathrm{s}), 8.59(1 \mathrm{H}, \mathrm{br} \mathrm{s}), 8.01-8.29(3 \mathrm{H}, \mathrm{m}), 7.86(3 \mathrm{H}$, br s $), 7.57$ - $7.77(6 \mathrm{H}, \mathrm{m}), 7.26(2 \mathrm{H}, \mathrm{t}$, $J=8 \mathrm{~Hz}$ ), 6.81 - 6.97 (3 H, m), 1.58 (27 H, br s); Shmadzu Axima cfr-plus MALDI-TOF-MS, m/z; calcd for $\mathrm{ZnC}_{61} \mathrm{H}_{48} \mathrm{~N}_{8} \mathrm{O} 972.32[\mathrm{M}+]$, obsd 972.78 .

7,8,17,18-Tetracyano-5-(4-formylphenyl)-10,15,20-tris(4-t-butylphenyl) porphyrin (5). Compound 19 (7 mg, $0.01 \mathrm{mmol})$, was dissolved in dichloromethane $(10 \mathrm{~mL})$ in a round bottomed flask equipped with a magnetic stir bar. Trifluoroacetic acid $(1.6 \mathrm{~mL})$ was added to the solution and the reaction mixture was stirred at room temperature for $3 \mathrm{~h}$. The reaction mixture was washed with a saturated solution of aqueous $\mathrm{NaHCO}_{3}(3 \times 50 \mathrm{~mL})$ followed by water $(2 \times 50 \mathrm{~mL})$. The organic layer was collected and dried over anhydrous sodium sulfate, the solvent was removed by distillation under reduced pressure and the product was dried under reduced pressure, yielding pure porphyrin $\mathbf{5}$ as a purple precipitate, $\mathrm{mp}>300{ }^{\circ} \mathrm{C}(6 \mathrm{mg}, 94 \%) ;{ }^{1} \mathrm{H}$ NMR $\delta(\mathrm{ppm}) 10.42(1 \mathrm{H}, \mathrm{s}), 8.99-9.10(3 \mathrm{H}, \mathrm{m}), 8.87$ $(1 \mathrm{H}, \mathrm{dd}, J=5,1 \mathrm{~Hz}), 8.27$ - $8.41(4 \mathrm{H}, \mathrm{m}), 8.04$ - $8.12(6 \mathrm{H}, \mathrm{m}), 7.79$ - $7.92(6 \mathrm{H}, \mathrm{m}), 1.55$ - $1.68(27 \mathrm{H}$, 
m), -2.42 (2 H, d, J=8 Hz,); Xevo G2-XS QTOF LC-MS/MS, ESI, m/z; calcd for $\mathrm{C}_{61} \mathrm{H}_{50} \mathrm{~N}_{8} \mathrm{O} 911.42$ $[\mathrm{M}+]$, obsd 911.42 .

CyP-C 60 dyad (3). Porphyrin 5, $\mathrm{C}_{60}$, and $\alpha$-phenylglycine were dried under vacuum for $6 \mathrm{~h}$. Porphyrin 5 (60 mg, $0.07 \mathrm{mmol})$, $\alpha$-phenylglycine $(100 \mathrm{mg}, 0.661 \mathrm{mmol})$, and $\mathrm{C}_{60}(100 \mathrm{mg}, 0.140$ $\mathrm{mmol})$ were dissolved in distilled toluene under argon in a round bottomed flask equipped with a magnetic stir bar and a reflux condenser. The reaction flask was placed in an oil bath heated to $120^{\circ} \mathrm{C}$, and the solution was refluxed for $9 \mathrm{~h}$. The reaction was allowed to cool to room temperature and then the solvent was removed by distillation under reduced pressure. The product was purified by column chromatography on silica gel using dichloromethane as the solvent, giving pure dyad 3 as a brown precipitate $(7 \mathrm{mg}, 12 \%) .{ }^{1} \mathrm{H}$ NMR $\delta(\mathrm{ppm}) 8.58-8.73(8 \mathrm{H}, \mathrm{m}), 8.38(2 \mathrm{H}, \mathrm{d}, \mathrm{J}=8 \mathrm{~Hz}),, 8.29(1 \mathrm{H}, \mathrm{s})$, $8.26(2 \mathrm{H}, \mathrm{d}, J=8 \mathrm{~Hz}), 8.00(2 \mathrm{H}, \mathrm{d}, J=8 \mathrm{~Hz}), 7.31(2 \mathrm{H}, \mathrm{d}, J=8 \mathrm{~Hz}), 7.25$ (6 H, s), 6.33 (1 H, s), 6.15 (1 H, s), $2.60(9 \mathrm{H}, \mathrm{s}), 2.40(3 \mathrm{H}, \mathrm{s}), 1.76-1.89(18 \mathrm{H}, \mathrm{m}),-2.58(2 \mathrm{H}, \mathrm{s})$; Applied Biosystems Voyager-DE STR MALDI-TOF-MS, m/z; calcd for $\mathrm{C}_{68} \mathrm{H}_{57} \mathrm{~N}_{9} 1000.24$ [M+ $-\mathrm{C}_{60}$ ], obsd 1000.06; calcd for $\mathrm{C}_{121} \mathrm{H}_{50} \mathrm{~N}_{8}$ 1615.75 [M- $\left.-\mathrm{C}_{7} \mathrm{H}_{6} \mathrm{~N}\right]$ obsd 1615.86; calcd for $\mathrm{C}_{61} \mathrm{H}_{50} \mathrm{~N}_{9} 909.11$ [M- $-\mathrm{C}_{67} \mathrm{H}_{7}$ ] obsd 910.02; calcd for $\mathrm{C}_{128} \mathrm{H}_{57} \mathrm{~N}_{9} 1720.88[\mathrm{M}+]$, obsd 1720.91.

P- $\mathbf{C}_{60}-$ CyP triad (1). Porphyrin 5, porphyrin 4, and $\mathrm{C}_{60}$ were dried for $4 \mathrm{~h}$ before use. Porphyrin 5 (10 mg, $0.01 \mathrm{mmol})$, porphyrin $4(10 \mathrm{mg}, 0.01 \mathrm{mmol})$, and $\mathrm{C}_{60}(16 \mathrm{mg}, 0.02 \mathrm{mmol})$ were dissolved in distilled toluene in a round bottomed flask equipped with a magnetic stir bar and a reflux condenser. The flask was placed in an oil bath that was brought to a temperature of $120^{\circ} \mathrm{C}$, and the reaction mixture was allowed to reflux for $19 \mathrm{~h}$. The reaction mixture was cooled to room temperature and the solvent was removed by distillation under reduced pressure. The product was purified by column chromatography on silica gel using 20\% hexane in dichloromethane as the solvent, giving pure $\mathbf{1}$ as a brown precipitate, $\mathrm{mp}>300{ }^{\circ} \mathrm{C}(5 \mathrm{mg}, 19 \%) ;{ }^{1} \mathrm{H}$ NMR $\delta(\mathrm{ppm}) 8.88-9.21(3 \mathrm{H}, \mathrm{m}), 8.50-8.87(9 \mathrm{H}$, m), $8.40(2 \mathrm{H}, \mathrm{d}, J=7.5 \mathrm{~Hz}), 8.25$ - $8.34(4 \mathrm{H}, \mathrm{m}), 8.20(2 \mathrm{H}, \mathrm{d}, J=8.3 \mathrm{~Hz}), 7.93-8.12(6 \mathrm{H}, \mathrm{m}), 7.67$ $7.92(7 \mathrm{H}, \mathrm{m}), 7.27(6 \mathrm{H}, \mathrm{s}), 6.31(1 \mathrm{H}, \mathrm{s}), 6.23(1 \mathrm{H}, \mathrm{s}), 2.61(9 \mathrm{H}, \mathrm{s}), 1.84(18 \mathrm{H}, \mathrm{m}), 1.52$ - $1.66(27 \mathrm{H}$, m), -2.40 (2 H, br s.), -2.56 (2 H, br s). Applied Biosystems Voyager-DE STR MALDI-TOF-MS, m/z; calcd for $\mathrm{C}_{115} \mathrm{H}_{99} \mathrm{~N}_{13} 1663.10$ [M+ - $\left.\mathrm{C}_{60}\right]$, obsd 1663.24.

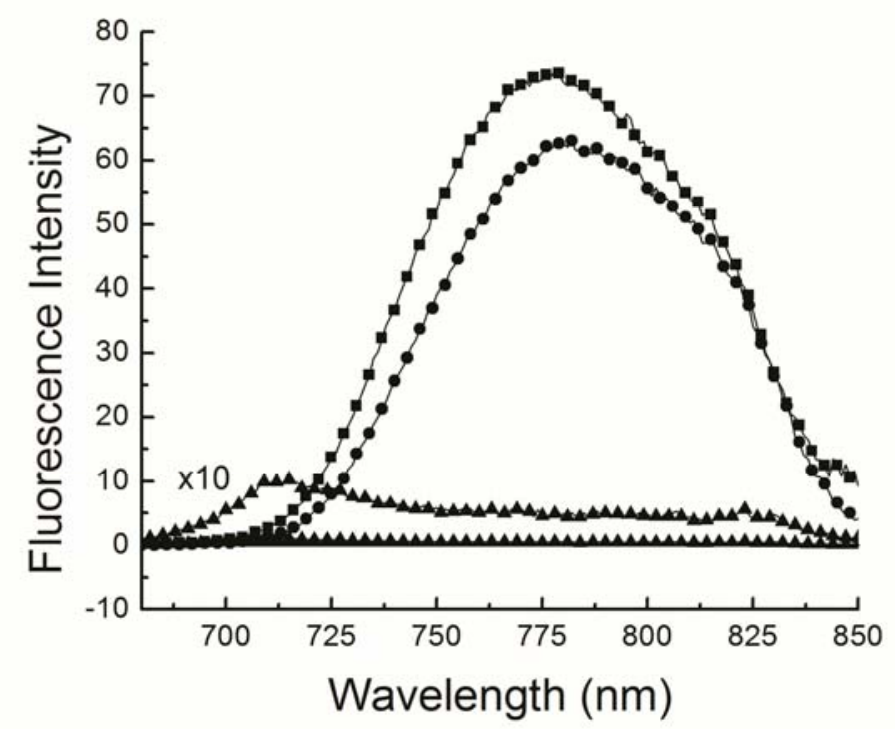

Figure S1. Fluorescence emission spectra in toluene with excitation at $320 \mathrm{~nm}$ of CyP model 5 (squares), CyP-C 60 dyad 3 (circles), and model fullerene (triangles). The fullerene spectrum is also 
shown with the intensity multiplied by 10 . All samples had the same absorbance at $320 \mathrm{~nm}$. From the absorption spectra of these compounds, it is found that in dyad 3 at $320 \mathrm{~nm}, 33 \%$ of the exciting light is absorbed by the CyP and $67 \%$ by the fullerene in dyad 3. Analysis shows an energy transfer efficiency from the fullerene to the CyP of $79 \%$ in dyad 3. 

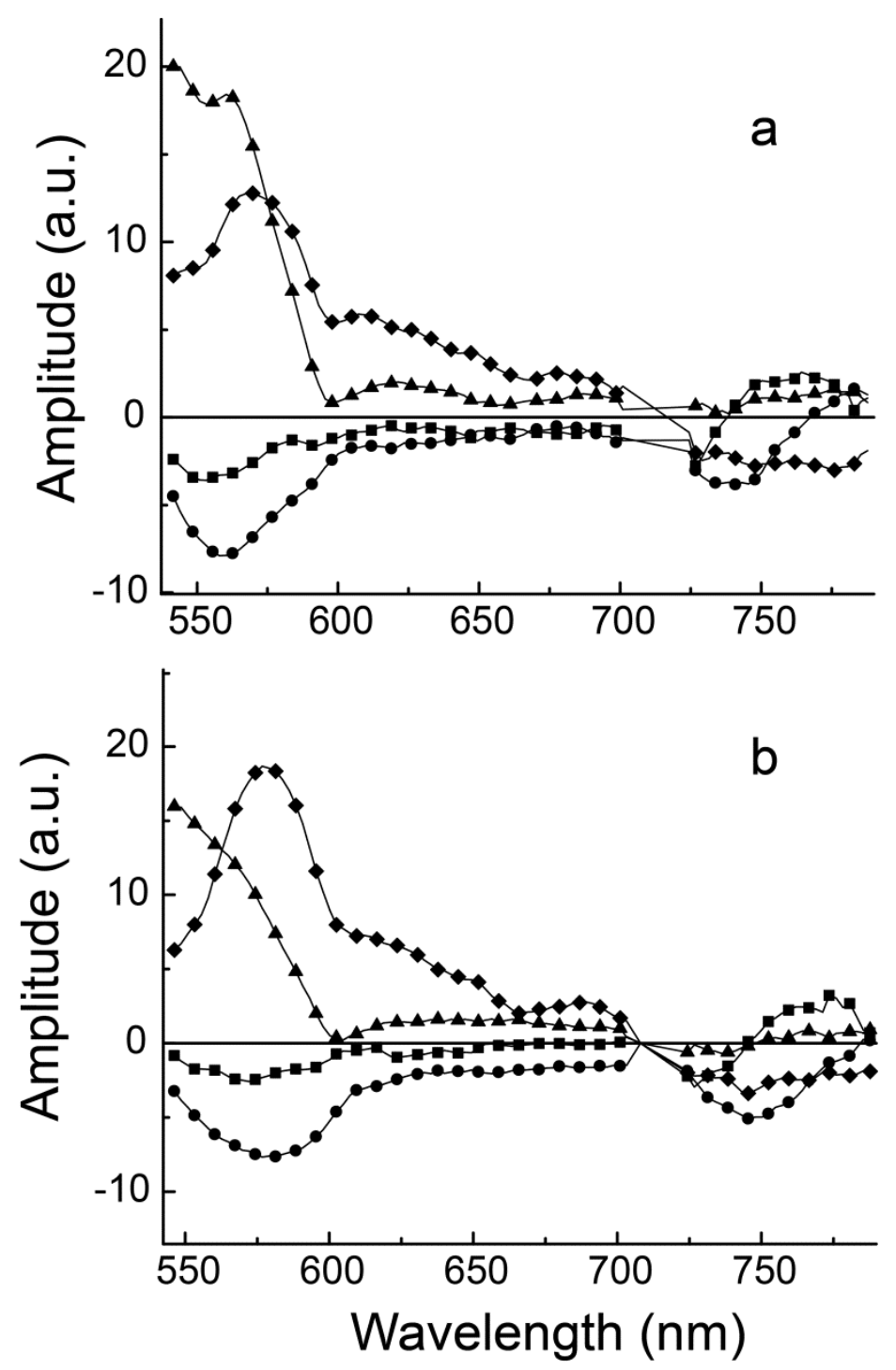

Figure S2. Transient absorption DAS from CyP 5 with excitation at $725 \mathrm{~nm}$. (a) In toluene solution: 1.5 ps (squares), 23 ps (circles), 2.11 ns (diamonds), non-decaying on the time scale used (triangles). (b) In benzonitrile solution: $2.9 \mathrm{ps}$ (squares), $50 \mathrm{ps}$ (circles), $1.8 \mathrm{~ns}$ (diamonds), non-decaying on the time scale used (triangles). 


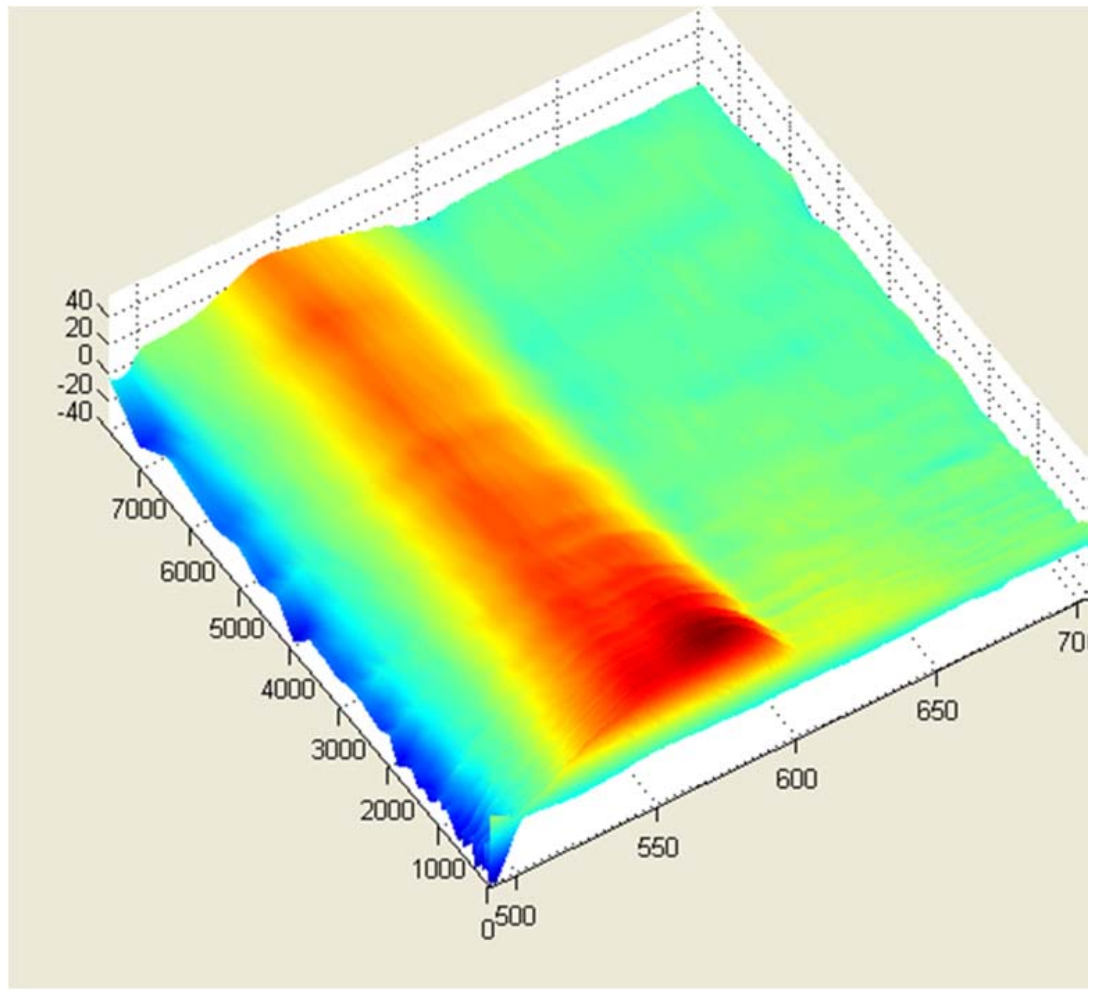

Figure S3. Transient absorption from CyP 5 with excitation at $725 \mathrm{~nm}$ in benzonitrile solution. The transient at $580 \mathrm{~nm}$ rises with 2.9 ps and 50 ps time constants, and it decays with a 1800 ps lifetime; there is non-decaying component seen in the $7000 \mathrm{ps}$ time delay transient at $550 \mathrm{~nm}$. 


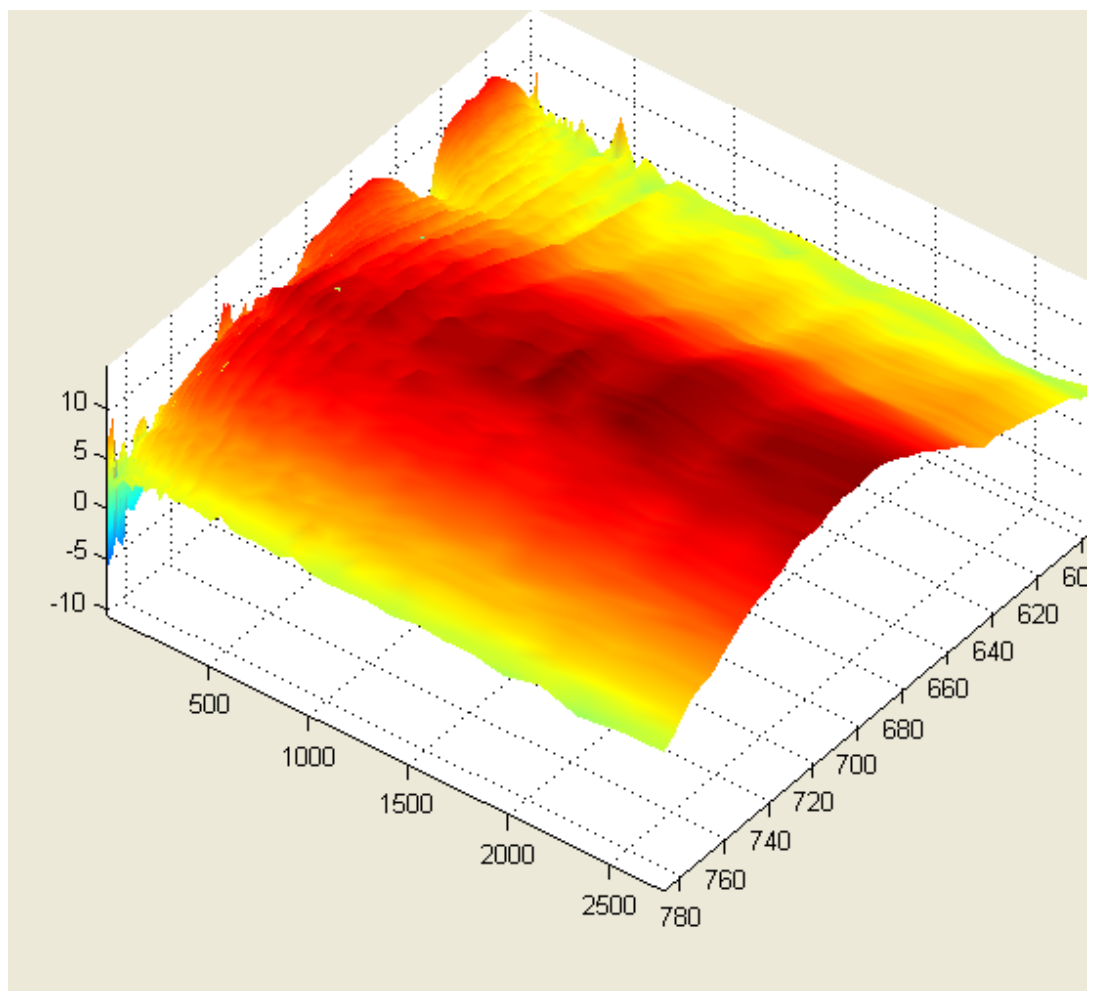

Figure S4. Transient absorption from $\mathrm{P}_{-} \mathrm{C}_{60}$ dyad 2 with excitation at $590 \mathrm{~nm}$ in toluene solution. The transient at $620 \mathrm{~nm}$ decays with a major $75 \mathrm{ps}$ lifetime. The transient at $700 \mathrm{~nm}$ rises with $75 \mathrm{ps}$ and 1900 ps time constants. This transient does not decay during the measurement time window of 2500 ps. 


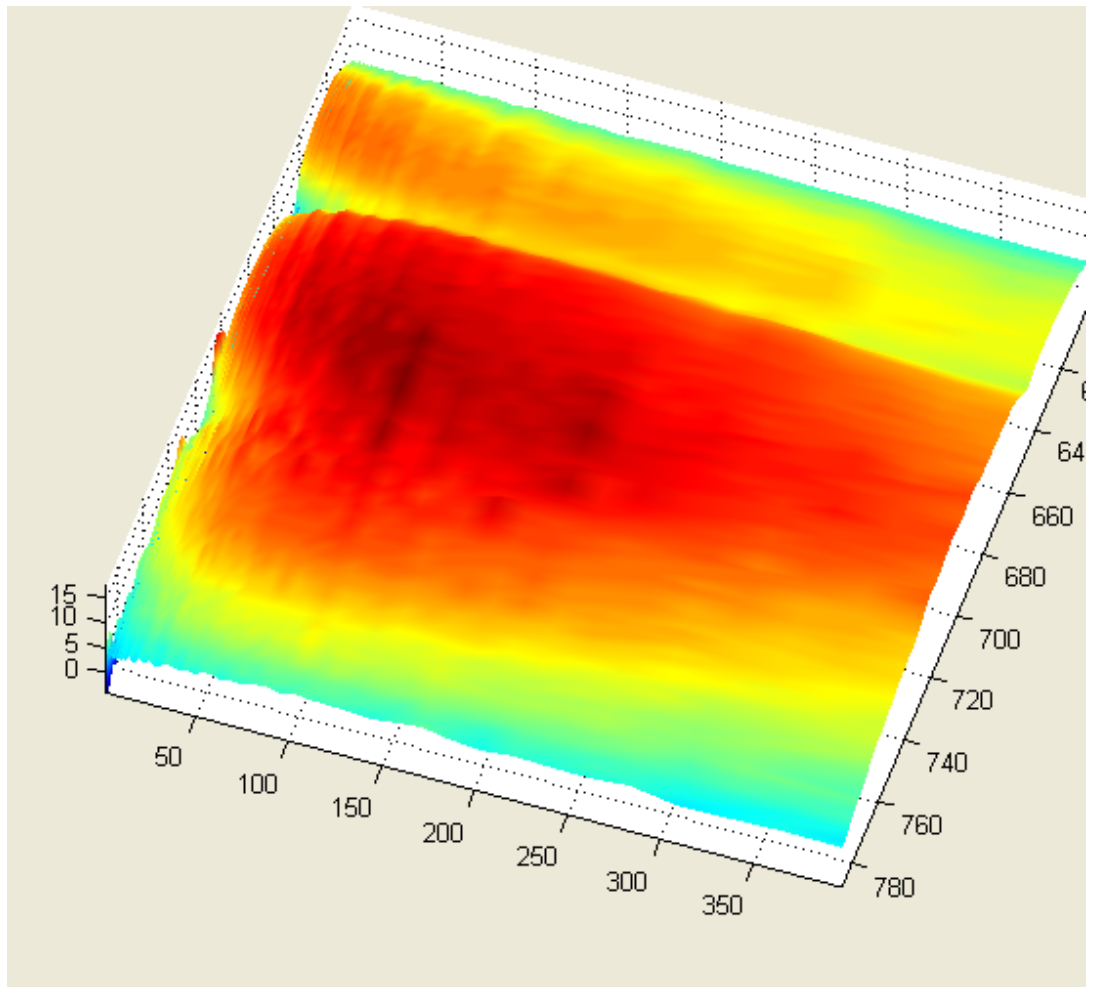

Figure S5. Transient absorption from $\mathrm{P}-\mathrm{C}_{60}$ dyad 2 with excitation at $590 \mathrm{~nm}$ in benzonitrile solution. The transient at $680 \mathrm{~nm}$ rises with 33 ps and decays with 660 ps time constants; there is a small nondecaying component seen in the 400 ps time delay transient at $700 \mathrm{~nm}$. 


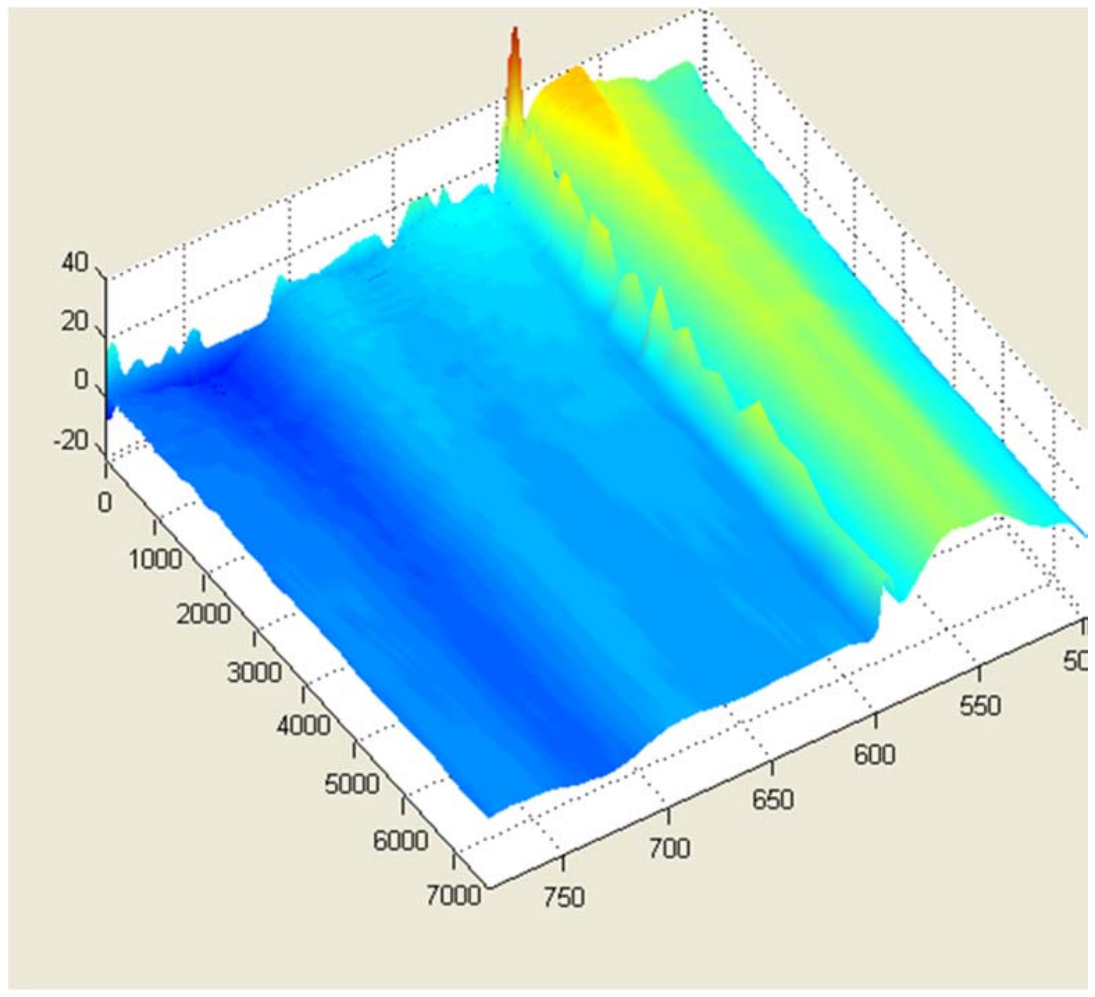

Figure S6. Transient absorption of $\mathrm{CyP}-\mathrm{C}_{60}$ dyad 3 with $595 \mathrm{~nm}$ excitation in toluene solution. The transients at $580 \mathrm{~nm}$ and $740 \mathrm{~nm}$ decay with a major 2200 ps lifetime; there is a non-decaying component seen in the 7000 ps time delay transient at $550 \mathrm{~nm}$. 


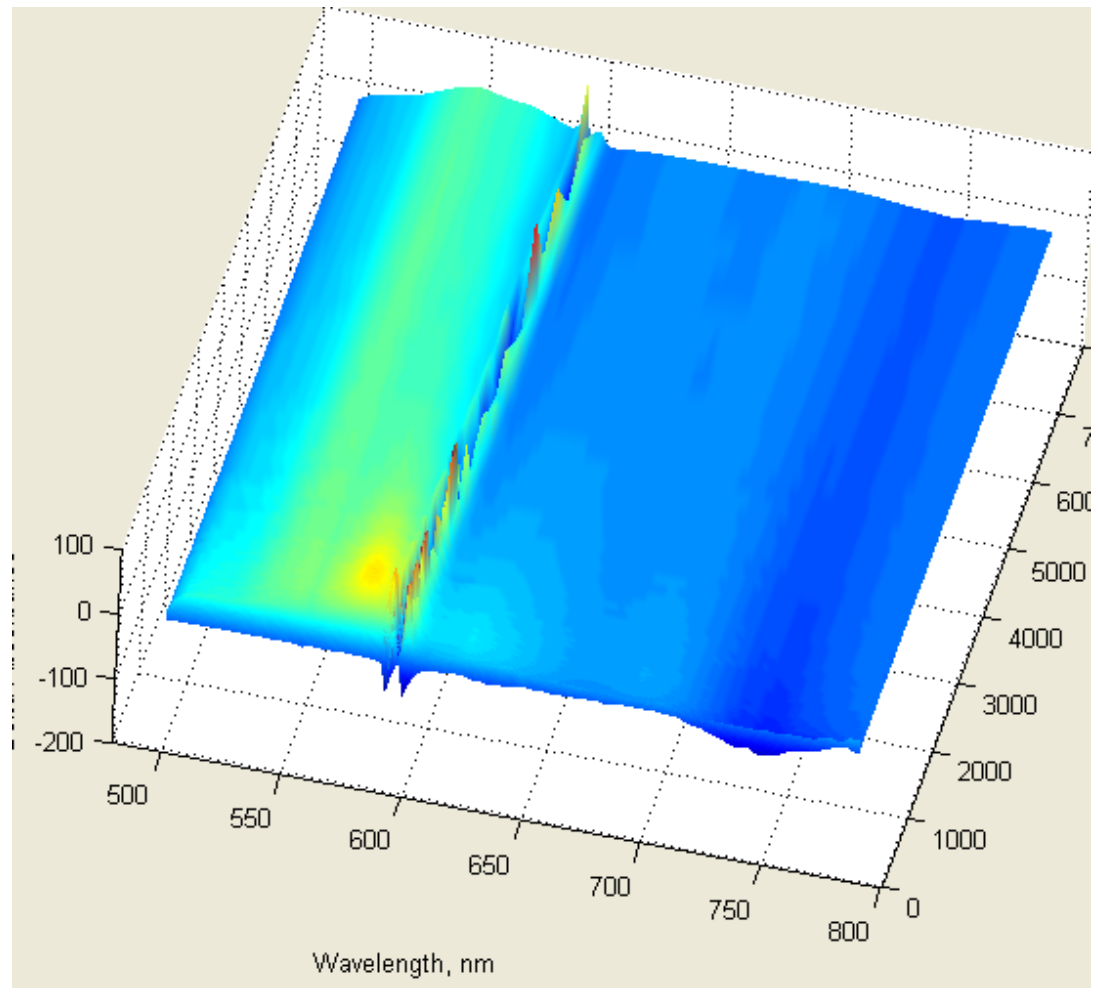

Figure S7. Transient absorption of CyP-C 60 dyad 3 with $595 \mathrm{~nm}$ excitation in benzonitrile solution. The transients at $580 \mathrm{~nm}$ and $740 \mathrm{~nm}$ decay with a major $1900 \mathrm{ps}$ lifetime; there is a non-decaying component seen in the 7000 ps time delay transient at $550 \mathrm{~nm}$. 


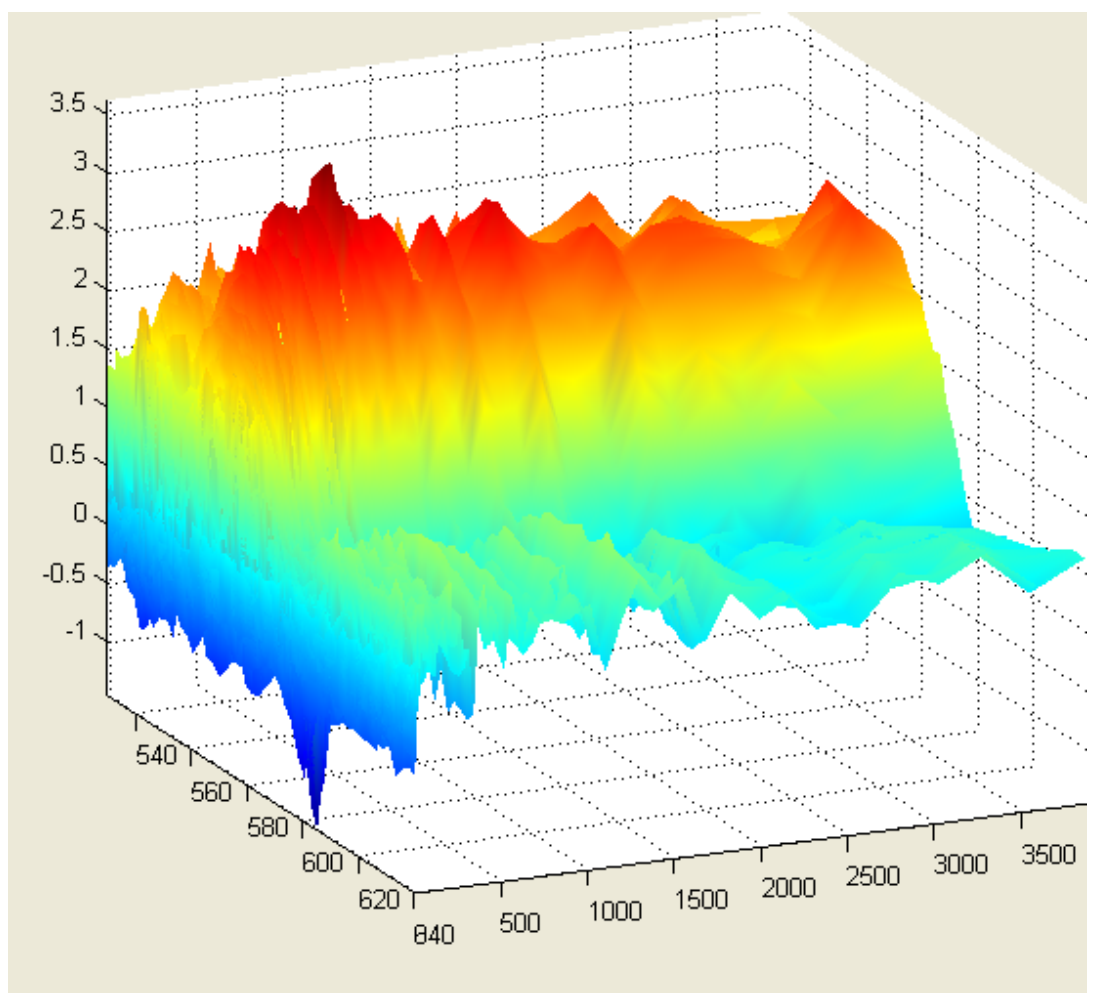

Figure S8. Transient absorption for triad 1 with excitation at $510 \mathrm{~nm}$ in toluene solution. The transient at $580 \mathrm{~nm}$ rises with $29 \mathrm{ps}$ and $143 \mathrm{ps}$ time constants, and it decays with a $2200 \mathrm{ps}$ lifetime; there is a non-decaying component seen in the $3500 \mathrm{ps}$ time delay transient at $550 \mathrm{~nm}$. 


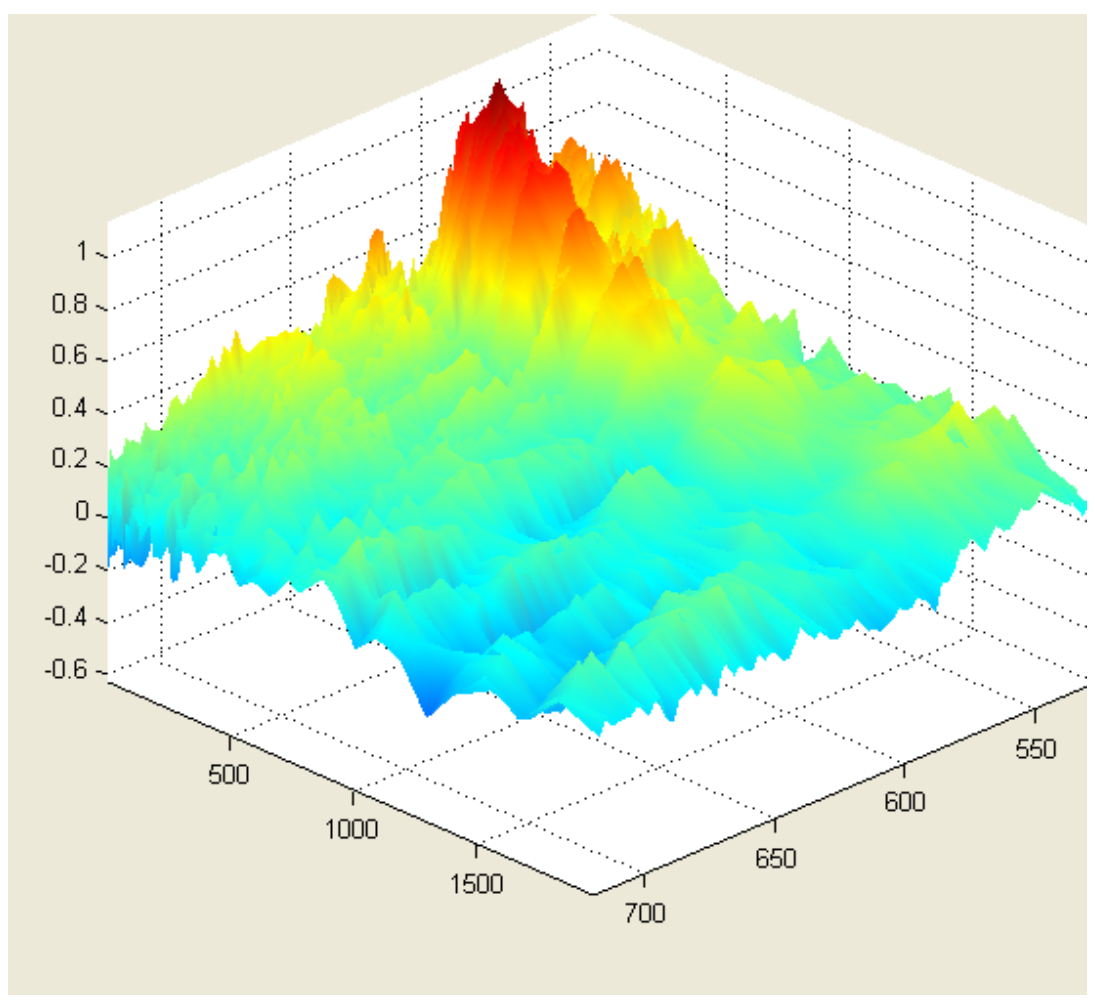

Figure S9. Transient absorption for triad 1 with excitation at $510 \mathrm{~nm}$ in benzonitrile solution. The transients at $580 \mathrm{~nm}, 620 \mathrm{~nm}$ and $660 \mathrm{~nm}$ rise with a $22 \mathrm{ps}$ lifetime and decay with a $350 \mathrm{ps}$ time constant; there is a transient at $550 \mathrm{~nm}$ which does not decay during the $1500 \mathrm{ps}$ time delay shown. 


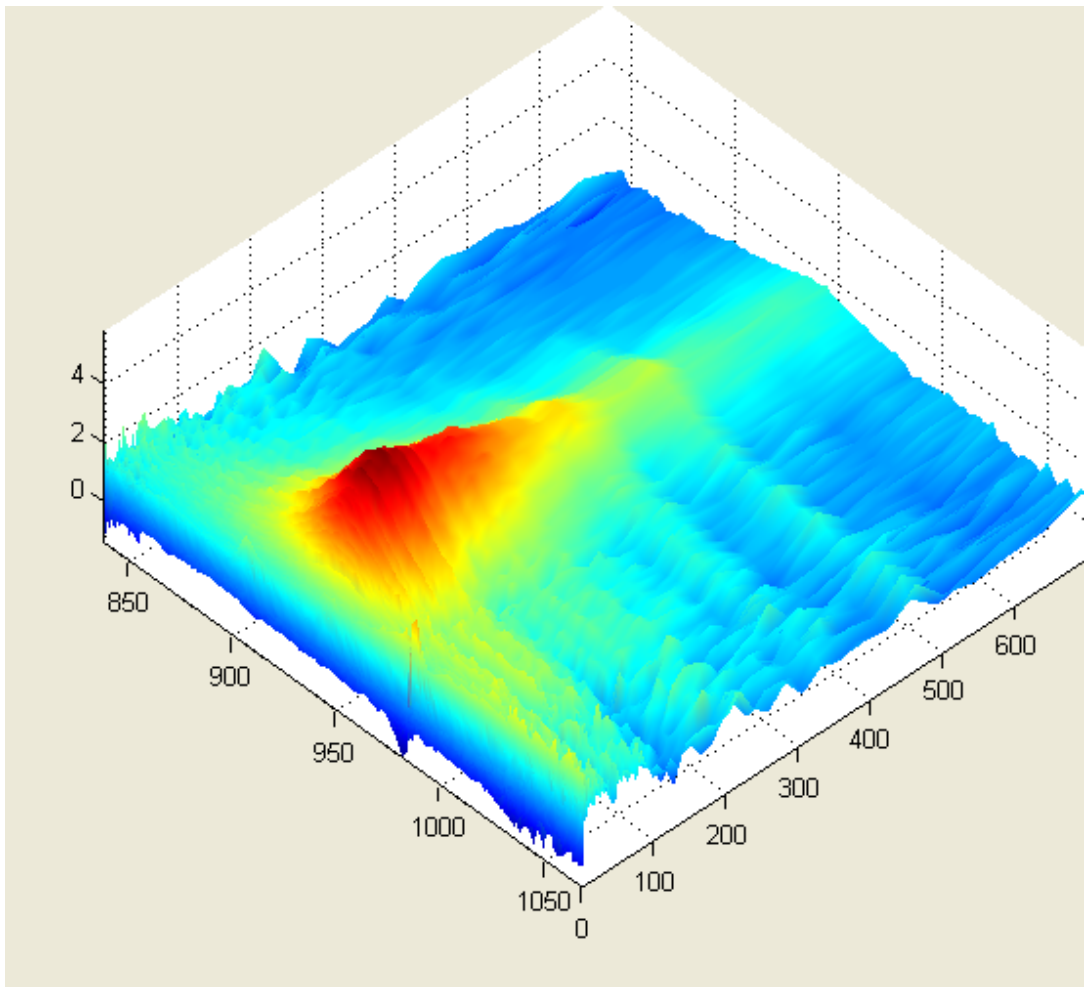

Figure S10. Transient absorption for triad 1 with excitation at $510 \mathrm{~nm}$ in benzonitrile solution (long wavelength region). The transient at $950 \mathrm{~nm}$ rises with a $22 \mathrm{ps}$ lifetime and decays with a $351 \mathrm{ps}$ time constant; there is a small non-decaying component in the 700 ps time delay transient at $920 \mathrm{~nm}$. 


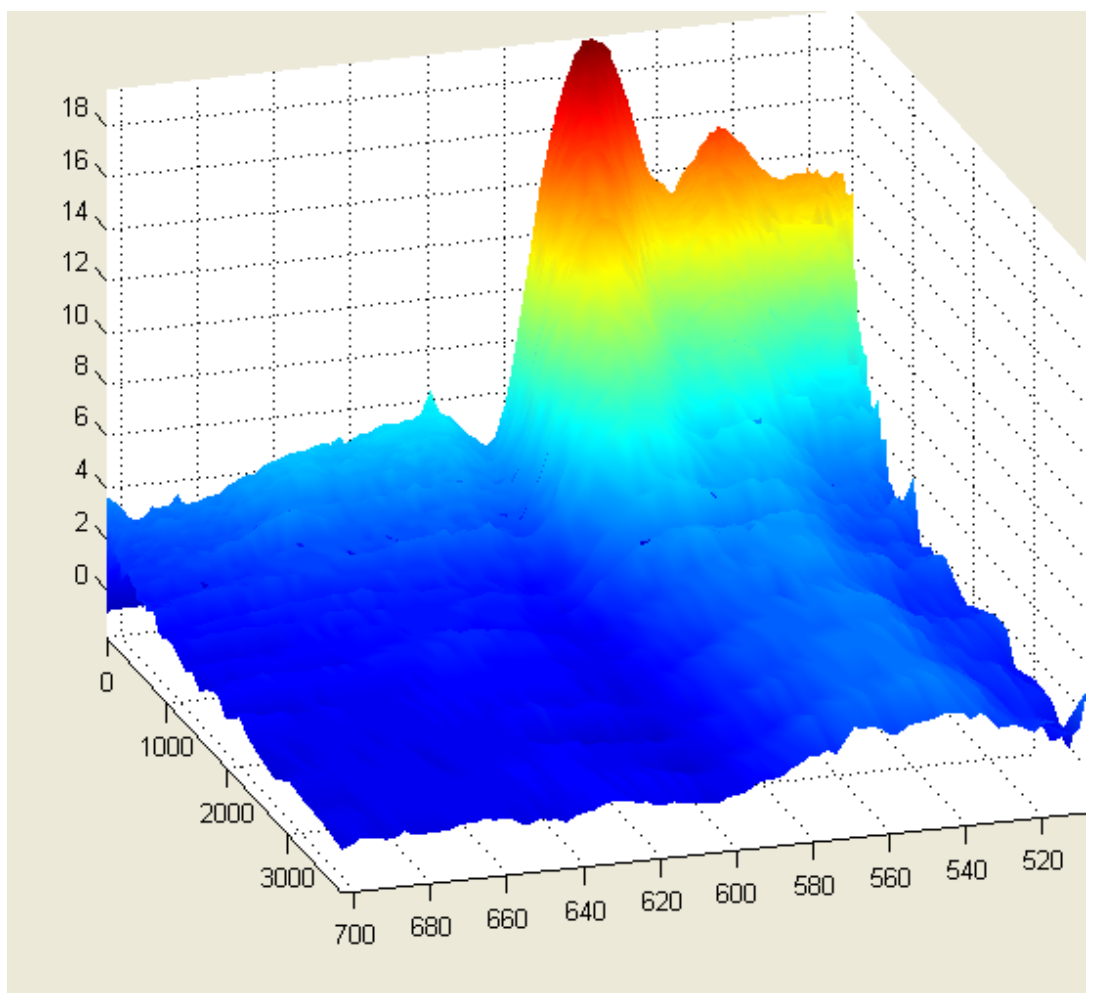

Figure S11. Transient absorption DAS of triad 1 in benzonitrile with excitation into CyP at $725 \mathrm{~nm}$. The transients at $580 \mathrm{~nm}$ and $660 \mathrm{~nm}$ rise with $14 \mathrm{ps}$ and 350 ps time constants; they decay with a 500 ps litime. There is a non-decaying component seen in the 3000 ps time delay transient at $540 \mathrm{~nm}$. 


\section{References}

(S1) Dogutan, D. K.; Zaidi, S. H. H.; Thamyongkit, P.; Lindsey, J. S. New Route to ABCDPorphyrins Via Bilanes. J. Org. Chem. 2007, 72, 7701-7714.

(S2) Wessendorf, F.; Gnichwitz, J. F.; Sarova, G. H.; Hager, K.; Hartnagel, U.; Guldi, D. M.; Hirsch, A. Implementation of a Hamiliton-Receptor-Based Hydrogen-Bonding Motif Toward a New Electron Donor-Acceptor Prototype: Electron Versus Energy Transfer. J. Am. Chem. Soc. 2007, 129, 16057-16071.

(S3) Rohand, T.; Dolusic, E.; Ngo, T. H.; Maes, W.; Dehaen, W. Efficient Synthesis of Aryldipyrromethanes in Water and Their Application in the Synthesis of Corroles and Dipyrromethenes. Arkivoc 2007, 307-324.

(S4) Benishai, D.; Altman, J.; Peled, N. Synthesis of Para-Substituted D,L-Phenylglycines by Amidoalkylation of Benzylchloride and N-Benzylbenzamide. Tetrahedron 1977, 33, 27152717.

(S5) Prato, M.; Maggini, M.; Giacometti, C.; Scorrano, G.; Sandona, G.; Farnia, G. Synthesis and Electrochemical Properties of Substituted Fulleropyrrolidines. Tetrahedron 1996, 52, 5221-5234. 